\title{
DEMityzaCja XIX Wieku We WSPóŁCZESNEJ POWIEŚCI NIEMIECKOJĘZYCZNEJ
}

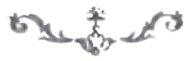

$S^{\prime}$

UKCES DEMASKATORSKICH KSIĄG Jakubowych Olgi Tokarczuk, które zdewaluowały konserwatywne marzenia o wielkiej osiemnastowiecznej Rzeczypospolitej tolerancyjnej i zunifikowanej, nakazywałby spojrzeć na podobne próby odwrócenia zależności pomiędzy mitem wieku XIX a jego odbiorcą czytającym historię jako narrację. Trudno powiedzieć, by był to przedmiot zainteresowania samych twórców narracji. Drogi powieści historycznej wyznaczają w najnowszej literaturze polskiej Andrzej Sapkowski (cykl Trylogia husycka, 2002-2006), Elżbieta Cherezińska (cykl Odrodzone królestwo, 2012-2014) czy Jacek Komuda (cykl Samozwaniec, 2009-2013), mieszający fantazję z faktem, fantastykę z realizmem, w końcu mit i historię, w ich spektrum pozostają jednak wieki wcześniejsze, przeszłość dająca się swobodnie kreować, czy to z braku jednolitego obrazu epoki, czy to na mocy stereotypowego oddziaływania, jakie wywiera na żądnego krwawej i żywiołowej opowieści czytelnika. Pożywką dla święcącej tryumfy literatury faktu ${ }^{1}$ oraz reportażu (Ryszard Kapuściński i jego liczni następcy) staje się jednak historia wieku XX. Wydaje się, że wiek XIX nie jest atrakcyjny dla współczesnych pisarzy polskich, abstrahując od kilku nazwisk, utożsamianych z quasi-dokumentalną literaturą „retro”, między innymi Jacka Dehnela czy Joanny Olczak-Ronikier.

Tendencja powrotów do wieku XIX w najnowszej (po roku 200o) powie-

1 Zob. M. Grzebałkowska, 1945. Wojna i pokój, Warszawa 2015. 
ści niemieckojęzycznej ma swoje korzenie w zainteresowaniu tematyką historyczną, jakie obudziły bestsellerowe książki w latach osiemdziesiątych i dziewięćdziesiątych minionego stulecia ${ }^{2}$, również pod wpływem sukcesu Imienia róży (1980) Umberta Eco. Sten Nadolny w Odkrywaniu powolności (1983) nakreślił obraz epoki wielkich odkryć naukowych, stawiających pytania o wartość człowieka i jego osiągnięć ${ }^{3}$. Bohater powieści, kapitan John Franklin, przez całe życie usiłujący odkryć Przejście Północno-Zachodnie w Arktyce, w końcu mianowany gubernatorem Tasmanii, ucieleśnia dwa wielkie marzenia XIX wieku: wypełnienie białych plam na mapach oraz zarządzanie tym, co już odkryte i podbite, oba natury politycznej. Pachnidło (1985) Patricka Süskinda to fantastyczna opowieść o wieku XVIII, ukazująca krajobraz epoki zasiedlonej przez "genialne potwory” ${ }^{4}$, której owocem będzie rewolucja ze wszystkimi konsekwencjami dla wieku kolejnego. Nieludzka natura głównego bohatera, geniusza węchu i seryjnego mordercy, jest mroczną, zmysłową oraz irracjonalną antytezą Oświecenia, jednocześnie zapowiedzią klęski epoki. W końcu Brat snu (1992) Roberta Schneidera bezwzględnie naświetla los geniusza otoczonego przeciętnością. Bohater powieści jest niezwykłym muzykiem - samoukiem, przewyższającym umiejętnościami swoich uczonych kolegów. Wychowany na prymitywnej prowincji, bez możliwości rozwoju, musi zginąć jako ofiara autocenzury kulturalnej, niepozwalającej na „dewiacje”, w tym przypadku na odstępstwo od reguły sprawiedliwości. W tej wizji talent nie jest darem Boga, lecz „Bez-Boga” darem przeklętym. Dziewiętnastowieczny ideał genialnego artysty - twórcy znajduje w powieści swoje dobitne, ironiczne zaprzeczenie.

Powieści Nadolnego, Süskinda i Schneidera wskazały na nowe tendencje w literaturze języka niemieckiego, przede wszystkim fascynację cudownością, niezwykłością, innością, podróżami i odkryciami. Sprzedawały się znakomicie, po dziś dzień zajmują poczesne miejsce w księgarniach i bibliotekach, do czego przyczyniła się również ekranizacja Pachnidła (2006, reż. Tom Tykwer). Przede wszystkim jednak doprowadziły do zatarcia granicy między

2 Tendencje powrotu do historyczności, z których wyrosła nowa powieść historyczna, Hans-Edwin Friedrich zauważa już w latach siedemdziesiątych. Zob. H.-E. Friedrich, Die Wiederkehr des historischen Romans seit den 1980er Jahren, w: Der historische Roman. Erkundung einer populären Gattung, hrsg. von H.-E. Friedrich, Frankfurt am Main 2013, s. 5-6.

3 Zob. S. Nadolny, Odkrywanie powolności, przeł. S. Lisiecka, posł. A. Stasiuk, Kraków 1999.

4 P. Süskind, Pachnidło, przeł. M. Łukasiewicz, Poznań 1998, s. 5.

5 R. Schneider, Brat snu, przeł. G. Kurpanik-Malinowska i F. Netz, Katowice 1996, s. 111. 
factum a fictum, co według Hansa-Edwina Friedricha jest jedną z fundamentalnych cech nowej powieści historycznej ${ }^{6}$. Warto przy tym zauważyć, że wspomniane teksty reaktywują tradycję realizmu magicznego, niezwykle mocną w literaturze niemieckiej, głównie dzięki takim nazwiskom, jak Hermann Hesse czy Günter Grass. Poza tym grają z popularnymi właśnie w XVIII i XIX wieku konwencjami literackimi: powieścią podróżniczą, awanturniczą, pikarejską, romansem, kryminałem, Heimatroman (idylliczną powieścią małych ojczyzn), wzbogacając je o elementy estetyki ponowoczesnej: ironię, umowność, świadomość gry, stylizację, parodię. Nieodłącznym składnikiem tych projektów jest zamysł demaskatorski, skłonność do weryfikacji oraz dekonstrukcji mitów społecznych i kulturowych, na czele z wcielonymi w życie epoki ideałami Oświecenia, wiarą w człowieka, przekonaniem o zbawczej misji nauki.

Rachuba świata (2005) Daniela Kehlmanna wprowadza powieść historyczną w XXI wiek. Jej ogromna popularność (około sześciu milionów sprzedanych egzemplarzy) może dowodzić, że hasła o renesansie gatunku nie są przesadzone. Zarówno powieść Kehlmanna, jak i Ein liebender Mann (Kochający mężczyzna, 2008) Martina Walsera, Imperium (2012) Christiana Krachta, Koala (2014) Lukasa Bärfussa oraz Pfaueninsel (Pawia Wyspa, 2014) Thomasa Hettche oferują oryginalne podejście do historii, podejmują przy tym wątki dziewiętnastowieczne, nie stroniąc od krytyki i odniesień do współczesności. W tym nurcie demityzacji XIX stulecia uwidaczniają się pewne, wykraczające poza sferę kreacji literackiej, zbieżności, dające się określić jako stałe cechy dyskursu o minionej epoce. Należą do nich dekonstrukcja mitu nauki, autorytetów, polityki kolonialnej, fascynacji egzotyzmem, w końcu romantycznej miłości.

\section{MIT NAUKI I POSTĘPU}

Daniel Kehlmann w całej swej twórczości szukał tematów i chwytów nietypowych. Począwszy od powieści Beerholm przedstawia (1997), w której ukazał historię niespełnionego matematyka-księdza-magika na tropie tajemnej formuły wszechświata, poprzez Mahlers Zeit (1999), gdzie w wyartykułowaniu znalezionej formuły przeszkadza sam język, Ich und Kaminski (2003) historię malarza, o którego biografię walczy żądny sensacji dziennikarz, aż po Rachubę świata, Kehlmann eksploruje pogranicza literatury i nauki, komizmu i powagi, możliwości metafikcji. W Rachubie świata prezentuje portret podwójny, fikcjonalizowane biografie znamienitych naukowców, Ale-

H.-E. Friedrich, dz. cyt., s. 9. 
xandra von Humboldta oraz Carla Friedricha Gaussa. Każdy z nich jest opętany żądzą zmierzenia świata, choć ich metody nie mogą się bardziej różnić. Humboldt podróżuje i mierzy każdy fenomen natury, wspomnienia publikuje w kilkudziesięciu tomach. Gauss, naukowiec za biurkiem, twierdzi, że wszechświat da się zbadać z dowolnego punktu na ziemi, stroni od wszelkiej publicity. Ten konflikt dwóch postaw każe zadać pytanie o trwałość metod badawczych, sens uprawiania nauki, w końcu - o dobroczynną moc postępu. Humboldt stoi po stronie Oświecenia i wierzy w swoją misję: „Kres drogi już niedaleko, prawie skończony jest pomiar świata i jego rachuba" 7 , wierzy również w prawdę obiektywną, niezależną od odkrywcy. Momenty zwątpienia przychodzą późno, nie opowiada o nich nikomu. Gauss nie ma złudzeń co do natury ludzkich dążeń:

Człowiekowi, ciągnął, wydaje się, że stanowi o sobie. Że coś tworzy, coś odkrywa, gromadzi dobra, znajduje sobie drugiego, którego kocha nad życie, płodzi dzieci, może mądre, a może gamoniowate, widzi śmierć kogoś ukochanego, starzeje się, głupieje, choruje i w końcu idzie do ziemi. Jak mu się zdaje, o wszystkim rozstrzyga sam. Dopiero matematyka pokazuje, że zawsze wybierał utarte szlaki. A tu jeszcze mowa o despotyzmie! Książęta to też jakieś nieszczęsne istoty, co żyją, cierpią i umierają jak wszyscy. Prawdziwymi tyranami są prawa przyrody.

Ale te prawa kształtuje ludzki rozum, odparł Humboldt.

Gauss pokręcił głową. Stare kantowskie bzdury! Rozum nic nie kształtuje i mało rozumie. ${ }^{8}$

Humboldt to człowiek XVIII wieku. Zgodnie z historią poznania, opisaną w Słowach i rzeczach przez Michela Foucaulta, reprezentuje epokę klasyczną, zainteresowaną taksonomiami i klasyfikacjami. Jego pamiętniki są wypełnione wynikami pomiarów, tabelami i wykresami, brak w nich narracji: „Wszelka mowa, naniesiona przez czas na rzeczy, zostaje zepchnięta

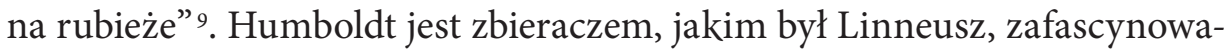
nym możliwościami „zliczania” różnic, lecz nie możliwościami poznania. Wiek, który wpuści człowieka do swych kalkulacji i zada pytanie o warunki i historię episteme już nastał - niepostrzeżenie. Humboldt, wierzący w niezmienność rzeczy, jest oświeceniowcem-optymistą, wyznawcą uniwersalnej potęgi rozumu, nie pyta o siebie i własne ograniczenia, jego autokreacja zmierza wprawdzie do ukształtowania medialnej formy własnego autorytetu - o czym później - lecz nie do samopoznania. Tu należy stwierdzić,

7 D. Kehlmann, Rachuba świata, przeł. J. Ekier, Warszawa 2007, s. 197.

8 Tamże, s. 181.

9 M. Foucault, Słowa i rzeczy. Archeologia nauk humanistycznych, przeł. T. Komendant, t. 1, Gdańsk 200o, s. 176. 
że Humboldt uprawia naukę empiryczną bez pytania o naturę empirii, naukę będącą pogłosem epoki wielkich odkryć geograficznych, w której świat był zbyt wielki i nieznany, zbyt przytłaczający, by można było wdawać się w dyskusje o miejscu człowieka jako podmiotu poznawczego.

Tymczasem zwrot do podmiotu badań naukowych, dokonujący się na przełomie XVIII i XIX wieku, skutkuje sceptycyzmem i upadkiem dogmatu bezgranicznego poznania. W człowieku miejsce znajduje również niewiedza:

Z tego względu refleksja transcendentalna we współczesnej postaci nie szuka już punktu oparcia - jak u Kanta - w istnieniu nauk przyrodniczych (którym przeciwstawiają się ciągłe swary i niepewność filozofów), ale w - niemym, gotowym przecież do mówienia i przenikniętym sekretnie potencjalnym dyskursem - istnieniu nieświadomego, stawiającym człowieka przed ścianą samoświadomości. ${ }^{10}$

W ten sposób Foucault mógłby podsumować obawy powieściowego Gaussa. Ten wydawać się może figurą osobliwą, mieszającą niewytłumaczalny pęd do odkrywania, bliższy w swej mrocznej naturze rewelacjom Schopenhauera niż Diderota, $\mathrm{z}$ barokowym niemalże poczuciem vanitas, z którego czyni swój znak rozpoznawczy. Sceptyk Gauss przeczuwa jednak więcej, niż pozwalałaby mu na to konwencja epoki minionej. Gauss widzi przełomy w myśleniu, które strącą podmiot z piedestału zdrowego i naiwnego racjonalizmu. Wie, że linie proste się zakrzywiają, choć nie potrafi jeszcze wyciągnąć z tego przeczucia konsekwencji ostatecznej. Wie o tym również Humboldt, lecz nic nie pojmuje. Teoria względności, nieśmiało objawiająca się poprzez irracjonalne lęki Gaussa, zakwestionuje przecież sto lat później wygodne umoszczenie człowieka w czasie i przestrzeni. Drugi cios nadejdzie ze strony psychoanalizy, która wskaże na władzę nieświadomości, o czym pisze Foucault, a której słuszność Gauss przeczuwa jedynie w ograniczeniach rozumu, trudno wytłumaczalnym cierpieniu człowieka oraz niemożności kierowania własnym życiem.

Na tle epoki przepełnionej euforycznym dążeniem do produkcji i eksploatacji, w której pobrzmiewają jeszcze wielkie hasła Oświecenia, Humboldt jest podmiotem koniecznym. To dzięki niemu, inaczej - dzięki odrzuceniu Humboldta, będzie możliwy przewrót dwudziestowieczny, przejście na ciemną stronę nowoczesności, ze wszystkimi jej deficytami. Jeżeli Oświecenie prowadzi do katastrofy, o czym nie wiedział Kant, odpowiadając na pytanie „Czym jest oświecenie?” (o czym wie Foucault dwieście lat później ${ }^{11}$, i pewnie

11 M. Foucault, Czym jest Oświecenie?, w: tegoż, Filozofia, historia, polityka. Wybór pism, przeł. D. Leszczyński i L. Rasiński, Warszawa 2000, s. 290. 
tylko dzięki przewadze czasowej nad Kantem), a typową postawą wieku XIX jest „nowoczesność”, dla której równie ważne jest poczucie nieciągłości czasu, jak i brak akceptacji siebie ${ }^{12}$, to przyszłość należy do Gaussa. Konflikt pomiędzy Humboldtem i Gaussem, w powieści zamknięty jedynie w dowcipną dysputę roku 1828, jest konfliktem paradygmatów nauki, historycznym napięciem epistemologii ${ }^{13}$ (dodajmy - wówczas ,jedynie słusznej” epistemologii Zachodu ${ }^{14}$ ), w końcu starciem dwóch najróżniejszych postaw, które można by naiwnie nazwać „życiowymi”, a które manifestują się w odmiennym stosunku do stylu, spędzania czasu, wykształcenia, interakcji społecznych, w końcu seksualności. Postaci Kehlmanna to figury odbrązowione, obrócone w narrację próby uczłowieczenia luminarzy postępu. Za odbrązowieniem podąża dekonstrukcja, niekiedy kompromitacja, a jej ofiarą padają największe umysły epoki.

\section{AUTORYTETY}

Ironiczny zamysł Kehlmanna mierzy również w niego jako autora. Mówi o sobie Gauss: „[...] za dwieście lat byle głupek będzie mógł na jego temat opowiadać żarty i fantazjować od rzeczy" "15. Gauss został wyposażony w zmysł umowności, co czyni z niego człowieka na wskroś nowoczesnego. Przeczuwa niekiedy, że jest wymyślony, nie ma jednak wielkiego szacunku dla stwórcy. To wybitnie relatywistyczna sytuacja narracyjna. Kehlmann nie gwarantuje prawdomówności, jest bowiem świadomy ograniczeń historycznych jednostki, nie tylko własnych bohaterów, lecz i samego siebie. Jego zamysł można nazwać heglowskim: ukazuje swe figury pośród dyskursów epoki, przepełnionych wiarą w słuszność ludzkich poczynań, kontrastując je przy tym z absurdami czasu, widocznymi dopiero z perspektywy współczesnej. Figury Kehlmanna tkwią w rzece historii, karmiąc się iluzją obiektywności i uniwersalności. Jedynie sceptycyzm Gaussa otwiera przejście do historycznego relatywizmu:

Jest pewne zjawisko, ciągnął profesor, dziwne i niesprawiedliwe, najlepszy dowód na niemiłosierną przypadkowość egzystencji. Otóż człowiek rodzi się w określonym

12 Tamże, s. 283, 285.

13 Obok diagnoz Foucaulta na temat uprawiania nauki należy wspomnieć o różnych podejściach do obiektywności w historiografii XIX wieku, które Hayden White przedstawia, konfrontując Rankego i Micheleta: H. White, Metahistory. The Historical Imagination in Nineteenth-Century Europe, Baltimore - London 1973, s. 190-192.

14 R.J.C. Young, Postkolonializm. Wprowadzenie, przeł. M. Król, Kraków 2012, s. 32-33.

15 D. Kehlmann, dz. cyt., s. 7. 
czasie i choćby chciał, nie potrafi się od niego wyzwolić. Nad przeszłością ma niegodną przewagę, a w oczach przyszłości staje się błaznem. ${ }^{16}$

Markus Gasser nazywa Kehlmanna demiurgiem, który każe Gaussowi skrytykować całe swe stworzenie ${ }^{17}$. Faktycznie Gauss jest instancją krytyczną epoki, mizantropicznym wieszczem współczesności. Jego przewaga to świadomość własnej bezradności. Nie mają jej inni bohaterowie Kehlmanna, uwikłani w śmieszne spory, z pełną powagą głoszący groteskowe idee. Humboldt dowodzący, że słońce nigdy nie umrze, regularnie bowiem odnawia swój „flogiston”, Wilhelm von Humboldt, wybitny filolog, przepełniony nienawiścią do sławnego brata, Immanuel Kant, geniusz zniedołężniały, na matematyczne rewelacje Gaussa odpowiadający „kiełbasa”, Goethe, geniusz sprawny, lecz niezrozumiały, sypiący barokowymi aforyzmami, wyznający idee neptunizmu - chłodnego wnętrza ziemi (co obala Humboldt prostym pomiarem temperatury w kopalni), w końcu powszechna nieufność wobec darwinowskiej idei ewolucji, niewiara w możliwość wzniesienia się w powietrze, teoria kosmicznego eteru oraz potępienie homoseksualizmu - to idee, które w na wskroś naukowym XXI stuleciu muszą wydać się co najmniej zastanawiające.

Śmieszność autorytetów jest śmiesznością epoki, której świadomość daje czytelnikowi wątłe poczucie wyższości. Zabiegi autoironiczne czynią z tego tekstu faktycznie powieść „historyczną”, osadzoną w określonym czasie i reprezentującą określony stan wiedzy. Tym samym gatunek powieści historycznej nie tylko oferuje możliwość wysondowania dyskursów minionych, na których tle rozwija się akcja utworu, lecz również diagnozuje aspekty kultury współczesnej, dające się określić mianem ponowoczesnych ${ }^{18}$. Ten zamysł metahistoryczny, ujawniający ograniczenia w myśleniu o historii oraz ułudę historiograficznej obiektywności, jest dziś cechą decydującą o przynależności gatunkowej do nowej powieści opisującej czas miniony. Historiografia, ukazana jako podmiot interpretacji, nie analizy, traci tym samym wyłączne prawo do przedstawienia przeszłości w kategoriach prawdy i fałszu ${ }^{19}$. Stąd

16 Tamże, s. 6.

17 M. Gasser, Das Königreich im Meer. Daniel Kehlmanns Geheimnis, Reinbek bei Hamburg 2013, s. 119.

18 E. Schilling, Der historische Roman seit der Postmoderne. Umberto Eco und die deutsche Literatur, Heidelberg 2012, s. 10.

19 R. Hauenstein, Der deutschsprachige postmoderne historische Roman: W.G. Sebalds "Die Ringe des Saturn” und „Austerlitz” als historiographische Metafiktionen, „Anuari de Filologia. Literatures Contemporànies" 2014, nr 4, s. 4. 
wizerunki autorytetów będą nie tylko narzędziem odbrązawiania mitu, lecz także epoki, która dokonuje nad nimi namysłu.

Kehlmannowski Goethe to postać groteskowa, łącząca w sobie dostojeństwo mistrza i komizm niespełnionego naukowca. Goethe to mit, książę poetów, bardziej czczony niż czytany - jak dowodzi W. Daniel Wilson ${ }^{20}$. Książka Wilsona wpisuje się w politykę odbrązawiania autorytetów, traktuje o homoseksualizmie w dziełach Goethego i jako praca naukowa byłaby niemożliwa w czasach współczesnych weimarskiemu polihistorowi. Goethe był i po części ciągle jeszcze jest nienaruszalny, to posąg reprezentujący wszystko, co „niemieckie”, oczywiście to „dobre niemieckie” - filozoficzny idealizm, piękno, dyscyplinę, umiłowanie sztuk, mit Fausta, wyważone zaangażowanie polityczne, edukację i rozwój. Ta nieprzystępna, nadludzka łaskawość prowokuje do uchylenia zasłony mitu.

Po Kehlmannie na pomnikową postać porwał się klasyk współczesnej literatury miłosnej i „po-miłosnej”, Martin Walser. Jego Ein liebender Mann również nie stroni od demityzacji naukowych. Nie tylko jako obrońca idei neptunizmu, również jako autor anty-newtonowskiej Farbenlehre wpisał się Goethe w annały nauki zmarginalizowanej. W powieści Walsera jest nękany krytyką współczesnych naukowców, którzy w jego teorii kolorów widzą marzenia niepoprawnego poety. Wiek XIX to już nie epoka Goethego. Dziwią go maszyny, przeciw którym występował w Wilhelmie Meistrze, dziwi go dynamika produkcji dóbr, a symbolem zmiany paradygmatu jest niejaki Graf Leuchtenberg, który pojawia się na balu maskowym przebrany za Prometeusza, zamiast ognia niosącego ludzkości maszynę parową.

Przede wszystkim jednak jest powieść Walsera próbą dotarcia do człowieka Goethego. Trudno wydobyć go spod warstw pudru i dekoracji, jakimi pokrył sam siebie, jakimi pokryła go następująca po nim kultura, już za jego życia omijająca go dookoła niczym nienaruszalny monument: „Goethe to rokoko. Kto to powiedział? Być może synek August. Jego zniweczone nasienie. Goethe to rokoko, on to wiek XIX” ${ }^{21}$. W innym miejscu o Weimarze: „Tam moje życie jest bardziej teatrem niż życiem” ${ }^{22}$, w końcu w momencie zwątpienia o swoim medialnym wizerunku: „[...] najszlachetniejsza fasada kultury Niemiec, Europy, całego świata, przykład wyrzeczenia dla nadchodzących czasów, wszyscy nieszczęśliwi powinni patrzeć w ciebie jak

20 W.D. Wilson, Goethe, Männer, Knaben. Ansichten zur „Homosexualität”, aus dem Englischen von Angela Steidele, Berlin 2012, s. 9.

21 M. Walser, Ein liebender Mann, Reinbek bei Hamburg 2008, s. 74. Wszystkie cytaty $\mathrm{z}$ niemieckiego $\mathrm{w}$ moim tłumaczeniu - R.P.

22 Tamże, s. 15. 
w gwiazdozbiór: tak trzeba radzić sobie z bólem” ${ }^{23}$. Ten ból to miłość do młodszej o pięćdziesiąt cztery lata Ulrike von Levetzow, tutaj pretekst jedynie do obnażenia człowieczeństwa Goethego, zburzenia mitu kreowanego już za życia, o czym wie sam Goethe, gdy czyta w prasie relacje weimarskich gości składających mu obowiązkowe, z góry „legendarne”, wizyty. Goethe staje się ofiarą własnej autokreacji, podczas wspomnianego balu nakłada kostium Wertera, jego ukochana zaś - Lotty, bez świadomości, że w roku 1823 taki gest może zostać uznany jedynie za sentyment ${ }^{24}$. Poczucie umowności konwencji staje się tym bardziej bolesne, gdy sytuacja życiowa, miłość, zmusza go do zejścia z wybudowanej przez siebie sceny. Zbyt późno dostrzega, że wszystko, co go otacza, to literatura.

Kehlmannowski Humboldt i Walserowski Goethe wprowadzają w epokę medialną, choć sami nie do końca o tym wiedzą. Humboldt każe sekretarzom spisywać własne światłe myśli, daje im tajemne znaki, gdy refleksja ma się pojawić, najczęściej w formie przemowy lub zgrabnego aforyzmu. Goethe w pancerzu własnego języka zamienia się w kolekcję cytowanych i przekazywanych dalej epigramów. Pierwsze pytanie Ulrike brzmi: gdzie pod tym wszystkim jest człowiek? Nieuchronnie pojawia się publiczność, z reguły taka, która nie wie, za co czci się niektóre figury. Moment tryumfu Goethego to jego urodziny, gdy witany jest muzyką i wiwatami. Dołącza do powszechnej euforii, płacze ze szczęścia, nie podejrzewając, że roztacza się przed nim nowoczesny teatr medialności, nie wiedząc naturalnie, że wiek następny przyniesie środki przekazu, zdolne do tego, by uczynić z kameralnej uroczystości globalny festiwal. W tych dwóch postaciach uwidacznia się specyfika wczesnego wieku XIX - przepełnionego wielkimi figurami czasu minionego, bez siły, by powstrzymać przemiany, o których nie śnił nawet Faust. Postawy i idee nowoczesne będą ucieleśniać Marx i Nietzsche, lecz to pokolenia następne. Goethe i Humboldt uwięzieni są w czasie „pomiędzy”, w którym mają dość medialnej prezencji, by nie popaść w zapomnienie i móc uwiecznić minione, za mało duchowego wpływu jednak, by znacząco napiętnować czas nadchodzący. Śmierć wielu znaczących postaci kultury u progu XIX stulecia (Herder, Kant, Schiller) zamyka pewną epokę, w tym kontekście Humboldtowi i Goethemu przypada rola własnych epigonów.

Tamże, s. 266.

24 Choć można go zinterpretować również poprzez sens mityczny miłości, cechę Erosa, jaką jest „próba zawieszenia czasu” - zob. L. Kołakowski, Obecność mitu, Warszawa 2003, s. 53. 
Pozostańmy na chwilę przy Humboldcie. Nauką i dobrobytem państwa usprawiedliwia konieczność rewizji osobistej robotników zatrudnionych w meksykańskiej kopalni srebra: „[...] bez przeciwdziałania prywacie górników nie wchodzi w rachubę regularna eksploatacja skarbów ziemi" ${ }^{25}$, mówi do dyrektora kopalni, któremu obojętne jest, ilu z nich ginie w wypadkach, chętnych do pracy jest dosyć. Dyrektor czytał Leibniza i Kanta, bez zachwytów jednak. Postawa kolonialna Humboldta nie polega jedynie na tym, że zwiedza i mierzy świat, jakby był jego własnością, kradnie kości z grobowców Indian i liczy wszy na ich głowach. Humboldt przede wszystkim nie widzi konsekwencji rzeczonej eksploatacji (niem. Ausbeuten - również wyzysk), zapatrzony w kosmos, poszukujący odwiecznych praw natury, pozostaje ślepy na przyszłość kolonii, ekonomiczne profity są dla niego równie abstrakcyjne. Krótka historia pruskiego kolonializmu (1884-1919) to historia wyzysku, przemocy i nierówności tłumaczonych ideami postępu. Oświeceniowy entuzjasta Humboldt wizytujący zamorskie kopalnie jest zapowiedzią tego szczególnego mariażu nauki i kapitalizmu ${ }^{26}$, wobec którego nie pozostaje dziś obojętna literatura postkolonialna.

Powieść Christiana Krachta Imperium ma dwóch bohaterów. Pierwszy to bohater zbiorowy - „Niemcy w zenicie swojego światowego wpływu” ${ }^{27}$, drugim jest August Engelhardt, który płynie do Nowej Gwinei Niemieckiej po to, by udowodnić tym pierwszym, że się mylą - że cywilizacja przynosi zło, a jedynym szczęściem jest „życie na wyspach”, odrzucenie stroju i odżywianie się orzechami kokosa. Rezygnuje tym samym z możliwości owego „światowego wpływu”, zgodnie z mottem, jakie Kracht kładzie pod tytułem: "Naked people have little or no influence on society” ${ }^{28}$ (Mark Twain). Engelhardt wyrusza w podróż z początkiem XX wieku, lecz wiezie ze sobą bagaż marzeń dwóch poprzednich stuleci. Kontekstem tej narracji są Przypadki Robinsona Crusoe, konwencja robinsonady, między innymi Insel Felsenburg Johanna Gottfrieda Schnabla, oświeceniowe utopie pokroju wyspy Nipu u Krasickiego, fascynacja kulturami „prymitywnymi”, której hołdował Diderot w Przyczynku do podróży Bougainville’a i którą dwuznacznie przed-

D. Kehlmann, dz. cyt., s. 163.

Jak dowodzi Jerzy Ronikier w kontekście dwudziestowiecznej edukacji historycznej, mit postępu miał uzasadniać rodzący się kapitalizm i zatajać popełnione jego kosztem zbrodnie - zob. J. Ronikier, Mit i historia. Mitotwórcze funkcje podręczników szkolnych, Kraków 2002, s. 121.

Ch. Kracht, Imperium, Frankfurt am Main 2013, s. 12.

Tamże, s. 7. 
stawił Voltaire w Prostaczku. Gest „powrotu do natury”, dokonany w nowoczesności, może tylko oznaczać klęskę, czego nie zataja ironiczna narracja. Engelhardt nie wraca do natury, ponieważ nigdy wcześniej w niej nie był, jest człowiekiem na wskroś przesiąkniętym cywilizacją i konwencją, karalnymi podówczas wybrykami (nudyzm) i ekstrawagancjami (wegetarianizm) tuszującym swoje osadzenie w społeczeństwie. Nagus spożywający kokosy w Nowej Gwinei ma stanowić kontrast dla wilhelmińskiej kolonialnej arystokracji, próbującej w tropikach odtworzyć rodzimą strukturę władzy.

Powieściowy Engelhardt wybiera się do Oceanii zbierać - dosłownie i w przenośni - owoce polityki dziewiętnastowiecznego kolonializmu, lecz jego postawa jest alternatywna. Zamierza zatem walczyć ze współczesną władzą, opartą na narzędziach produkcji, przybierając postawę prostaczka. Jako idealista spóźniony o sto lat symbolizuje klęskę myślenia utopijnego w obliczu nowej ekonomii. Powieść Krachta jest miażdżącą demityzacją wyobrażeń o powrocie do natury, zarazem jednak niebezpośrednią krytyką kolonializmu ze wszystkimi jego zawłaszczeniami. Kracht nazywa swojego bohatera romantykiem, aluzyjnie wspomina innego „późnego niemieckiego romantyka”, w którym daje się rozpoznać Hitlera ${ }^{29}$. Ta paralela, dla niektórych otwarta manifestacja neonazistowskich poglądów autora ${ }^{30}$, może zostać również odczytana jako krytyka totalitaryzmu ufundowanego na ezoterycznym umiłowaniu natury, ziemi i krwi, w którym rolę sług i zbieraczy pełnią autochtoni, jakże różni od swych oświeceniowych „pierwowzorów”, teraz jako warstwa najniższa w aryjskim pacyficznym raju.

Historyczny August Engelhardt umiera w roku 1919 na wyspie Kabakon, Kracht jednak każe swojej literackiej figurze żyć dłużej. Wyrzucony z krainy szczęśliwości przez australijskich żołnierzy u progu pierwszej wojny światowej, Engelhardt staje obok Hansa Castorpa (Czarodziejska góra), którego pobyt $\mathrm{w}$ hermetycznym środowisku szwajcarskiego sanatorium również przerywają wydarzenia roku 1914, oraz obok bohatera Niecierpliwości serca Stefana Zweiga, w ten sam sposób „wybawionego” od wyrzutów sumienia po tragicznej miłości. O ile dalszy los Castorpa nie jest czytelnikowi znany, to o powieściowym Engelhardcie można powiedzieć, że czeka go świetlana przyszłość - na ekranach kin. Oto bowiem jego historią interesuje się Hollywood, i tak właśnie kończy się powieść Krachta - obrazem filmowym odtwarzającym pierwszą scenę powieści.

30 Polemikę na ten temat rozpoczyna Georg Diez w artykule Die Methode Kracht („Spiegel” 2012, nr 7, s. 100-103). 
Za ciekawą koincydencję należy uznać fakt, że kwestię kolonizacji Oceanii podejmuje w swojej powieści Koala inny uznany szwajcarski pisarz, Lukas Bärfuss. Ta metoda jest jednak odmienna, forma, do której dąży, wybitnie hybrydyczna. Narrator rozpoczyna od wspomnień o zmarłym bracie, który wybrał sobie torbacza koalę za harcerski totem. Próbę wyjaśnienia jego samobójczej śmierci podejmuje w Australii przed dwudziestoma milionami lat, tworząc $w$ ten sposób bezprecedensowy konglomerat historii naturalnej, historii ludzkości i autobiografii. Całą drugą część tekstu zajmuje narracja o Terra Australis, w pierwszej fazie kolonizacji - naturalnym więzieniu, miejscu zsyłki brytyjskich przestępców od końca XVIII wieku. Krytyka postkolonialna powieści koncentruje się wokół dwóch motywów: epidemii ospy wśród Aborygenów w roku 1789, tuż po lądowaniu pierwszych osadników, oraz masowego wytępienia koali w XIX i XX wieku. Oba motywy reprezentują nowoczesny mechanizm wyniszczenia:

To, co wyróżniało człowieka, to jego ambicja, nieprzerwane dążenie, niemożliwość bezruchu. Skutek strachu, który przyszedł na świat wraz z nim, on był strachem, i strach był nim, on przyniósł strach światu, strach był jego wynalazkiem, jego wkładem w historię naturalną, i człowiek nigdy nie ustał w swojej ambicji, by go stłamsić. Wiedza o własnej nieuniknionej zagładzie napawała go przerażeniem, i nigdy nie mógł opanować tego przerażenia. Bóg umarł, ale strach żył dalej. ${ }^{31}$

W biblijnych niemalże tyradach wylicza Bärfuss przyczyny rozwoju cywilizacji oraz przyczyny jej klęski. Pilność, dyscyplina, praca - ideały Oświecenia - mają za podstawę egzystencjalny lęk, który zwraca się zawsze na zewnątrz. W tym ujęciu każda wiedza, uprawianie nauki, ujarzmienie natury będzie zawładnięciem, tak jak chce tego Nietzsche.

\section{FASCYNACJA EGZOTYZMEM}

Akcja powieść Thomasa Hettche Pfaueninsel rozpoczyna się w roku 1810, gdy królowa Luiza Pruska, żona Fryderyka Wilhelma III, zauważa w ogrodach Pawiej Wyspy karła: „I tak trafiło Marie w końcu jej słowo, dalekosiężna strzała, którą było słowo i która tak długo miała w niej tkwić, długo po śmierci królowej i przez całe życie małej dziewczynki. Potwór" ${ }^{32}$.

Marie i Christian to para karłów zamieszkujących Pawią Wyspę koło Poczdamu, która w latach 1793-1840 została zagospodarowana jako żywe muzeum osobliwości. Marie, piastująca tytuł damy dworu, zawiaduje tam grupą egotycznych postaci, jest wśród nich olbrzym i polinezyjski tubylec.

L. Bärfuss, Koala, Göttingen 2014, s. 167.

Th. Hettche, Pfaueninsel, München 2016, s. 14. 
Poza tym na wyspie hoduje się rzadkie zwierzęta, w palmiarni zaś egzotyczne rośliny. Wyspa, osiągalna jedynie drogą wodną, jest celem wycieczek królewskiej rodziny i dworu, sama Marie natomiast pełni funkcję nieoficjalnej gospodyni.

Za idylliczną stroną powieści kryje się narracja o nierówności, dyskryminacji, wstydzie i tabu. $Z$ wielkim dystansem, sięgając do arsenału nowoczesnej literatury realistycznej, autor dodaje do tej historii drugie i trzecie dno, ukrytą krytykę marzeń wieku XVIII, przemian wieku XIX, destrukcji wieku XX. Karzełka Marie jest świadkiem stulecia (nie bez znaczenia jest tu na pewno wpływ Blaszanego bębenka), ponadto - jako „oryginalna” dama dworu i królowa udawanej „tropikalnej” wyspy - produktem fascynacji egzotyzmem, która przeniknęła Zachód w dobie kolonizacji. Pragnienie, by zebrać w jednym miejscu ludzi z zakłóceniem wzrostu, nie-Europejczyków oraz zwierzęta i rośliny w zamyśle „pasujące” do niezwykłości „ludzkich eksponatów", obnaża zarówno deficyty oświeceniowego myślenia o nietkniętej cywilizacją egzotyce, jak i politykę rasową z jej dwudziestowiecznymi konsekwencjami. Pfaueninsel jest ujęciem tego samego problemu, który podejmują powieści Krachta i Bärfussa - sposobu prowadzenia polityki kolonialnej, tu jednak z perspektywy najbliższej, bo spod samego Berlina, jednej ze stolic oświeconej Europy. Oto fascynacja dziwnością i zarazem nieskrywana odraza - słowo „potwór” mieści w sobie różnorakie konteksty, które we współczesnych dyskursach postkolonialnych i genderowych wybrzmiewają o wiele wyraźniej niż u progu XIX stulecia. Narzucona Marie potworność będzie jej niechcianą naturą, zwalczaną przez całe życie, czyli przez cały wiek.

Wraz ze śmiercią Marie na wyspie wygrywa pruska dyscyplina - zwierzęta udają się do zoo, plantacje zostają zarzucone, kończy się epoka ogrodów, pawi i stylizowanych ruin. Nadchodzi wiek pary, symbolizowany przez podberliński Feuerland (ziemię ognia), gdzie produkuje się stal, szyny i wagony. Wyspa była jedynie przednowoczesnym kaprysem, pozostałością mrzonek o egzotycznej idylli, kultywowanych od czasu wielkich odkryć geograficznych. Piękno okazuje się wartością względną, motywowaną politycznie.

\section{ROMANTYCZNA MIŁOŚĆ}

Marie ma jeszcze jeden problem - własną seksualność. Jest uwikłana w kazirodcze uczucie do brata, erotyczne przywiązanie do nawiedzającego ją niekiedy króla, w końcu w niespełnioną miłość do rezydującego na wyspie ogrodnika. Jako człowiek „spoza normy” nie ma prawa do takich doznań. $\mathrm{W}$ tej panoramie wyparcia nie jest jedyna, problem ze swoim homoseksu- 
alizmem ma również Alexander von Humboldt z Rachuby świata. Pierre Lepape dowodzi, że model miłości romantycznej oparty jest na mitach, po dziś dzień dominujących kody powieści i filmu ${ }^{33}$. W tych mitach nie ma jednak miejsca na Inność. Głosy peryferyjne mają szanse zostać usłyszane dopiero w procesie demityzacji, taką szansę oferuje im Hettche w Pfaueninsel, taki grunt przygotowuje Walser w Ein liebender Mann. Nawet w „bezpiecznych" ramach narracji o związku heteroseksualnym jest miejsce na tabu u Walsera jest nim starość. Jednak jego projekt demaskatorski jest wycelowany przede wszystkim w samą postać mecenasa romantycznej miłości.

Wróćmy do sceny, w której Goethe i Ulrike tańczą w strojach Wertera i Lotty: „Demonstrowali, że cały świat nie jest w stanie przeszkodzić dwojgu kochankom. Wyraźnie wykraczali poza swoje osobowości, stawali się rolą, stawali się kostiumem, stawali się Lottą i Werterem" ${ }^{34}$. Nawet rana na skroni, jakiej nabawia się Goethe, upadając w przerwie, zostaje przez gości balu zinterpretowana jako dowcipne i realistyczne nawiązanie do śmiertelnego postrzału Wertera. Tak w pierwszej części powieści miłość Goethego jest z papieru, żywi się minionym, obojga kochanków wtłacza zaś w przygotowane uprzednio role. Ponieważ jednak związek nosi znamiona skandalu, poeta sięga do sprawdzonych środków: chce legitymować swą miłość poprzez literaturę, uczynić siebie i Ulrike postaciami powieści pod tytułem Ein liebender Mann. Ta jednak nie pozwala się napisać, jak było to dotychczas, zmienia się w strumień świadomości, intymne wyznanie cierpiącego miłość człowieka. Ostateczne wyjście Goethego z wtórnej narracji, w której uwięził się sam, prezentuje jego wypowiedź o napisanej pod wpływem miłosnego zawodu Elegii Marienbadzkiej: „[...] życie nie potrzebuje elegii, życie gardzi elegią” ${ }^{35}$. Pojawiają się tu z jednej strony zapowiedzi nowoczesnej fascynacji Niewyrażalnym, granicy języka, na której zaczyna się enigmatyczne „życie”, z drugiej strony - gest odrzucenia literackości jako żywiołu wtórnego.

Stary Goethe w stroju Wertera zapowiada przełom w przeżywaniu uczucia. Eva Illouz datuje początek komercjalizacji romantycznej miłości na koniec wieku XIX, osadza ją w kontekstach kapitalizmu i marksistowskiej „walki klas”. Pierwsze zmiany zapowiada sekularyzacja romantycznej miłości, wyłamanie się spod patronatu religii, jej awans do poziomu nowej religii, po którym następuje medializacja uczucia i romantyzacja produktów, w końcu sprzężenie miłości i konsumpcji w doznaniach „intensywności” i „zabawy” ${ }^{36}$.

P. Lepape, Une histoire des romans d'amour, Paris 2011, s. 189.

M. Walser, dz. cyt., s. 102.

35 Tamże, s. 242.

36 E. Illouz, Der Konsum der Romantik. Liebe und die kulturellen Widersprüche des 
Na poły groteskowa „Werteriada” weimarskiego mistrza uświadamia, że jego literatury nie można już dłużej tylko przeżywać - należy jej użyć, zmodyfikować, urynkowić i sprzedać. Tak jak Goethe i Ulrike, tak i kolejne pokolenia będą mogły odnaleźć się w kostiumach Lotty i Wertera, grać ich role, zakodowane na stałe w kulturze europejskiej od końca XVIII wieku, bez konieczności zastanawiania się, czy czynią słusznie. Komercjalizacja romantycznej miłości utwierdzi zatem stereotypowy podział ról przypisywanych obu płciom, począwszy od rytuałów uwodzenia aż po obcowanie intymne i życie w rodzinie.

\section{DIALEKTYKA DEMITYZACJI}

„Logika mitu, podobnie jak logika snu, godzi bez trudu radykalne sprzeczności. Nikt nie analizuje i nie rozwiązuje problemów zawartych w mitach" ${ }^{37}$ czytamy w Orientalizmie Edwarda W. Saida. Zadziwiające godzenie przeciwieństw, przede wszystkim postępu i wyzysku, idealizmu i liberalnej ekonomii, w kulturze XIX wieku prowadzi do wytworzenia niezwykle mocnych mitów. Osobliwą dialektyką dotknięte są również omawiane powieści. Choć nader krytyczne i sięgające do trudnych dyskursów współczesności, sprzedają się znakomicie, również na fali fascynacji minionym światem mieszczańskim, podróżami i literaturą w stylu retro. Proces rozpoczęty w latach osiemdziesiątych przez Odkrywanie powolności i Pachnidło nie słabnie. Z jednej strony można określić go jako żmudną drogę do nowej definicji siebie i określenia własnej pozycji wobec przeszłości, głównie wobec mitu Oświecenia, czego chciałby Foucault ${ }^{38}$, $\mathrm{z}$ drugiej jako proces ponownego ożywienia atrakcyjnej formy. Po sprawdzone środki stylistyczne realizmu konsekwentnie sięgają Kracht i Hettche, zabiegi formalne wszystkich autorów każą myśleć o tradycji gatunkowej powieści i jej funkcji w literaturze współczesnej. Zarówno gry z gatunkiem (powieść historyczna - Kehlmann, robinsonada - Kracht), jak i formy hybrydyczne (pamiętnik, esej i relacja z podróży w jednym - Bärfuss, dziennik i powieść epistolarna przeplatane formami lirycznymi - Walser) odwołują się wyraźnie do przeszłości, mówiąc o przekroczeniu nowoczesności, odrzuceniu dyktatu eksperymentu na rzecz zabawy formą. Strategia pisania o XIX wieku jest dialektyczna - z jednej strony wymierzona krytycznie w mity stulecia, $\mathrm{z}$ drugiej przepojona nostalgią za minionym

Kapitalismus, aus dem Amerikanischen von A. Wirthensohn, Frankfurt am Main 2007, s. 52-56. 
światem przednowoczesnym i nowoczesnym, co objawia się w podjęciu na nowo popularnych w XVIII oraz XIX wieku konwencji.

Niedobór takich zabiegów w literaturze polskiej można tłumaczyć oczywiście modą na gatunki czy autorów, za którymi stoi określony styl i podejście do formy, otwierających pole krytycznej selekcji tekstów, gdzie szansę na przebicie mają utwory tendencyjne. Prymat literatury faktu w ostatnich latach w Polsce zakłada zainteresowanie teraźniejszością. Jednak przezwyciężenie romantyzmu w teatrze i poezji ostatnich dziesięcioleci nie mówi wiele o samym wieku XIX. Romantyzm jest traktowany jako źródło stereotypów postrzeganych ideologicznie, nie historycznie. Te polsko-niemieckie różnice dają się wytłumaczyć również bardzo odmiennymi kontekstami dziejowymi. Rachuba świata Kehlmanna ożywia czas, w którym Niemcy nie byli jeszcze obciążeni przeszłością i winą (Volker Hage) ${ }^{39}$, ewentualnie wskazuje na korzenie niemieckiej klęski w XX wieku (Adam Krzemiński) ${ }^{40}$. Dodajmy, że czyni to w ponowoczesnej formie parodystyczno-popularnonaukowej ze szczyptą gnozy i magii. Ten temat jest atrakcyjny dla czytelnika na Zachodzie, podczas gdy czytelnik polski woli jednak czytać o winach Niemców w okresie nazizmu - stąd obecność odpowiedniej niemieckiej literatury autobiograficznej i dokumentalnej w Polsce (m.in. Günter Grass, Martin Pollack, Uwe Timm). Ironiczne podejście do autorytetów jest traktowane w kręgu niemieckojęzycznym z dużą swobodą, w kulturze polskiej mogłoby to prowokować kontrowersje. Literatura postkolonialna w Niemczech ma mocne podstawy bytu, równolegle do niej można czytać dobrą literaturę imigrantów, u nas są to zjawiska jak na razie nieznane. Bez wątpienia na tym nie kończą się możliwe analogie. Obecność mitu jest w literaturze polskiej rozumiana inaczej, odmiennie będą zatem funkcjonować projekty demityzacyjne.

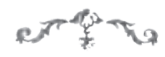

A B S T R A C T

\section{Demythologisation of The $19^{\text {Th }}$ Century}

in the Contemporary German Novel

The article presents contemporary German historical novels: Measuring the World by Daniel Kehlmann, Ein liebender Mann (A Loving Man) by Martin Walser, Imperium by Christian Kracht, Koala by Lukas Bärfuss and Pfaueninsel (Peacock Island) by Thomas Hettche. These novels criticise the popular myths of the $19^{\text {th }}$ century: the myth

39 V. Hage, Letzte Tänze, erste Schritte. Deutsche Literatur der Gegenwart, München 2007, s. 82.

40 A. Krzemiński, Rozmiar buty, „Polityka” 2008, nr 16, s. 69. 
of science, great authorities, colonial policy, fascination with exoticism, and romantic love. The new historical novel appears not only to be a critical project concerning past discourses, but also a diagnosis of contemporary historiography. Writing about the $19^{\text {th }}$ century is a dialectic strategy: on the one hand, critically directed against the myths of the century, on the other hand, full of nostalgia, manifested in the return to the classic conventions of historical, travel, and adventure novels, which are employed by contemporary writers.

\section{K E Y W O R D S}

Christian Kracht, Daniel Kehlmann, German historical novel, historiography, Lukas Bärfuss, Martin Walser, myth, Thomas Hettche 